\title{
Bilateral black hypopyon in a patient with self-healing cutaneous malignant melanoma
}

\author{
R. P. L. WORMALD ${ }^{1}$ AND JOHN I. HARPER ${ }^{2}$ \\ From the Departments of ${ }^{1}$ Ophthalmology and ${ }^{2}$ Dermatology, Westminster Hospital, London
}

SUMMARY A case is presented of a patient with clinically regressing cutaneous malignant melanoma who lost vision due to the accumulation of black material in the anterior chamber of both eyes. A hypothesis is presented, in the light of reviewed literature, suggesting the likely cause of visual loss.

Since Ernst Fuchs's publication on sarcoma of the uveal tract, ${ }^{1}$ in which he stated that malignant melanoma does not metastasise to the eye, more than 40 cases have been reported. ${ }^{2-28}$ An autopsy series of 15 patients who had died from disseminated cutaneous malignant melanoma, and who had no ocular symptoms, showed a $33 \%$ incidence of ocular metastases. ${ }^{29}$

The case is reported here of a man who, because of spontaneous regression of his disease, lived long enough to develop an unusual manifestation of bilateral ocular involvement in the form of black hypopyon. Only 2 cases, both unilateral have previously been recorded.

\section{Case history}

In April 1980 a 56-year-old man presented to a dermatologist with multiple 'blue spots' which had appeared over his body in the preceding 3 months. A large black mole on his back had gradually enlarged over a period of 20 years. A clinical diagnosis of disseminated cutaneous malignant melanoma was made, which was confirmed histologically from a biopsy of a nodular lesion on the leg.

In the subsequent months several of the palpable lesions on his body became flat, leaving an area of residual melanin pigmentation. (Figs. 1a, 1b).

In November 1980 the patient developed a right iridocyclitis with secondary glaucoma. Because of failure to respond to treatment, the sight of this eye gradually failed. Large amounts of pigment were present in the anterior chamber, and it began to form a black hypopyon. In February 1981 a pigmented

Correspondence to Dr R. P. L. Wormald, 71 Colvestone Crescent. London E8 2LJ. lesion was seen nasal to the disc in the left fundus. Before it was photographed vision in this eye was obscured by sudden vitreous haemorrhage. Over the next few months pigment began to accumulate in the anterior chamber of the left eye just as it had done in the right.

For these crippling catastrophes he attended his local hospital, and over a year supervened before he reattended the Westminster Hospital. $\mathrm{He}$ was readmitted in August 1981. Apart from his profound loss of vision his general health had remained good. The only evidence of active disease were enlarged lymph nodes in the right inguinal region, which softened and became smaller over the next 3 months. $\mathrm{He}$ had diffuse hyperpigmentation of the skin (melanosis cutis), most prominent on his face, which was studded with pinhead-size pigmented lesions.

Ocular findings were as follows: there was no perception of light in the right eye, with only a temporal island of light perception in the left. There was marked bulbar conjunctival and episcleral injection in both eyes. The corneas were clear but pigmented keratic precipitates were scattered over the endothelial surfaces. The lower half of the right anterior chamber and quarter of the left were filled with dark brown pigment (Figs. 2a, 2b, 2c, 3). Both pupils were completely bound down, the iris being coated with pigment. The aqueous in both eyes was a golden brown colour and there were many pigmented cells in suspension. Both lenses were opaque, with pigmented deposits on the anterior lens capsule. Intraocular pressures were $35 \mathrm{mmHg}$ in the right eye and $32 \mathrm{mmHg}$ in the left. No red reflex could be seen in either fundus.

Ultrasound examination of the right eye showed a detached vitreous gel tethered to the optic disc with a 


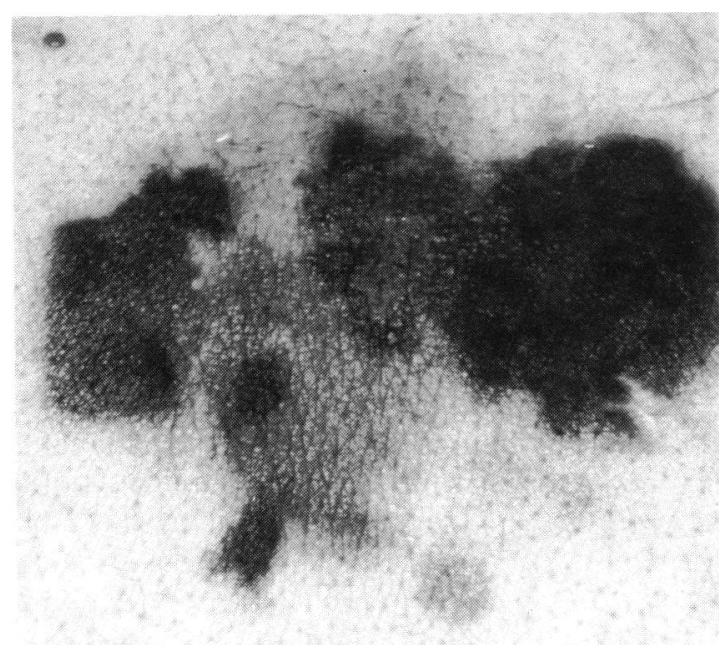

Fig. 1a July 1980: large pigmented tumour on the patient's back.

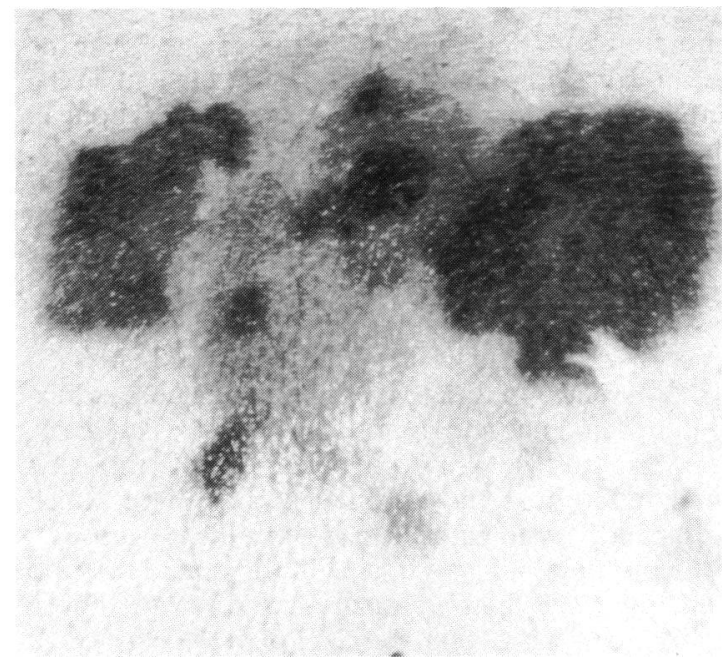

Fig. 1b August 1981: the same tumour having become flatter, smaller, and paler.

dense opacity in the anterior cortical vitreous. The left showed a highly mobile detached vitreous with an irregularly raised retinal surface nasal to the disc, an appearance compatible with a secondary mass (Fig. 4).

Systemic investigations including chest and skull $x$-ray, CT scan of brain and orbits, liver isotope and ultrasound scans, plasma calcium, and electrolytes were all within normal limits. A skin biopsy taken in November 1981 from the lesion on the back was reported as: 'melanin pigmentation around dermal vessels with streaking of melanin in the collagen; no epidermal abnormality; appearance consistent with regressed melanoma.'

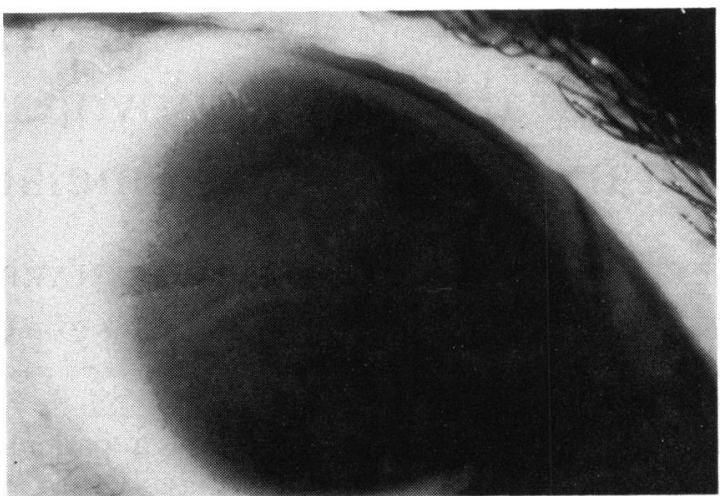

Fig. 2a Right eye.

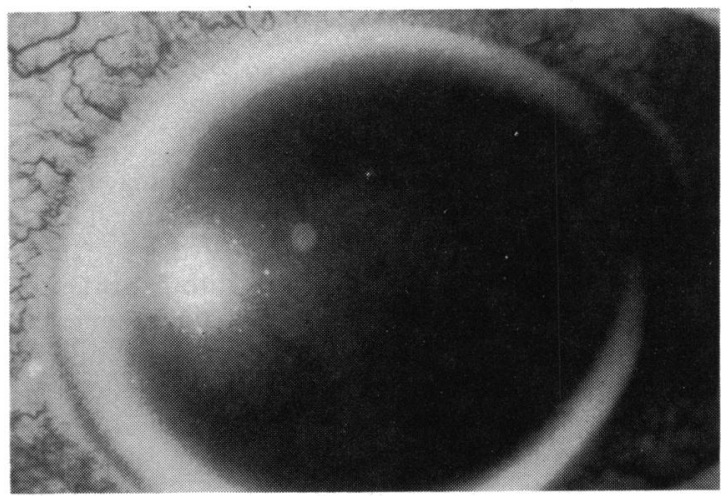

Fig. 2b Left eye.

Immunological investigations showed: immunoglobulins, normal; protein electrophoresis, raised alpha 1 and alpha 2 globulins; $T$ and $B$ cell studies showed a $\mathrm{T}$ lymphopenia (inducible in vitro with thymosin (TP-1) to normal); urinary melanogens, strongly positive; 24 -hour urinary cysteinyl dopa, 850 $\mu \mathrm{g}$ (August 1981) rising to $33000 \mu \mathrm{g} 3$ months later (normal range $450 \mu \mathrm{g}$ without prior exposure to sunlight).

These findings suggest that an immunological 'attack' was being mounted against the tumour cells, causing regression of the melanoma. In view of this it was felt that therapeutic intervention at this stage was not warranted, as it could theoretically adversely interfere with host defences.

On 28 December 1981 the patient died suddenly at his home. A coroner's post-mortem established the cause of death as myocardial infarction due to coronary occlusion. Extensive coronary atheroma was found, but in addition black deposits were noted around the coronary vessels in several places. Black deposits filled with tarry liquid were found in the brain and liver. The eyes were not obtained for study. 


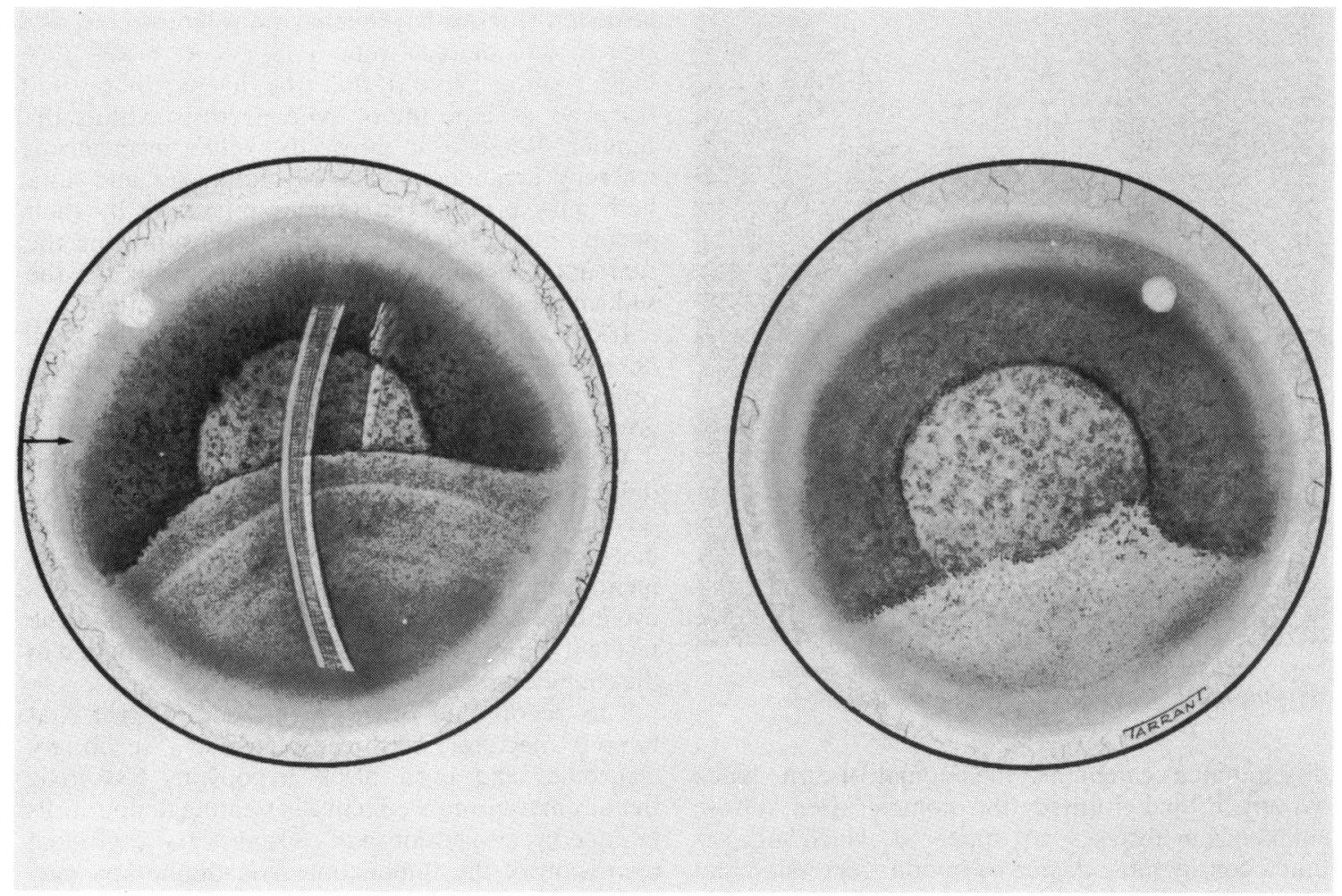

Fig. 2c Artist's illustration of right and left eye together. The arrow indicates the right eye.

\section{Discussion}

Because the patient was aware of his diagnosis and unwilling to undergo any invasive investigation which was not essential, no ocular paracentesis was undertaken to determine the nature of the material in his anterior chambers. It cannot therefore be definitely concluded that the ocular findings were due to secondary spread from a cutaneous primary. The history and the behaviour of the tumour rule out the possibility of an ocular primary with cutaneous secondaries. The third possibility of simultaneous bilateral choroidal melanomata and a separate primary cutaneous melanoma is equally unlikely, although 2 such cases have been described. In both instances there were predisposing factors; the B-K mole syndrome in one and ocular melanosis in the other ${ }^{30}{ }^{31}$ There was no evidence for such factors in this patient. On clinical grounds alone it is assumed that the ocular findings were secondary to the cutaneous disease.

There is good evidence that the melanoma was under active immunological 'attack.' A pigmented tumour was seen in the left fundus in January 1981, and this was borne out by the ultrasound findings.
There were no such findings in the right eye, but there was a dense opacity in the anterior cortical vitreous which could have been related to a secondary in the ciliary body. If it is accepted that secondary tumour was present in both eyes, it is reasonable to assume that these tumours were under the same immunological attack. It is suggested that this attack resulted in necrosis and break-up of the secondary masses, which in turn gave rise to black hypopyon, secondary glaucoma, and cataract.

Published reports give evidence to support this hypothesis. Albert et al. (1974) reported one of the only 2 previous cases of black hypopyon. ${ }^{32}$ They presented a case of disseminated cutaneous melanoma with a secondary in the ciliary body which broke up after a course of radiotherapy to form a black hypopyon. A diagnostic paracentesis showed that the hypopyon consisted of tumour cells and pigment-laden macrophages. Pathological examination of the enucleated eye revealed a necrotic tumour mass in the ciliary body with widespread dispersal of tumour cells and macrophages. Tumour cells were found invading the paracentesis track.

The other report of black hypopyon was published by Char et al. ${ }^{33}$ They also presented a case of 


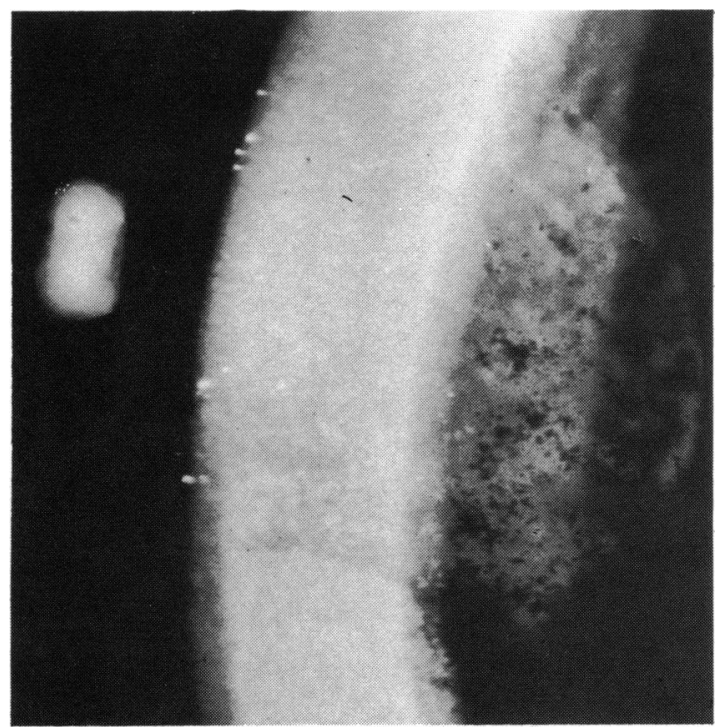

Fig. 3 High power view of the patient's right cornea showing pigment deposits on the endothelium.

disseminated cutaneous melanomatosis. A black hypopyon had formed 18 months after diffuse cutaneous metastases had appeared, which suggests that a considerable degree of tumour regression had been achieved in response to the immunotherapy which the patient had received.

In Reese et al.'s study of necrosis of choroidal melanomata, ${ }^{34}$ a case is described in which a large choroidal primary was observed while undergoing spontaneous regression. The eye was enucleated after a sudden vitreous haemorrhage was interpreted as a sign of tumour reactivation. However, histopathological study showed that the haemorrhage had occurred as a result of lytic necrosis within the tumour. Reese et al. go on to explain mechanisms whereby immunocompetent lymphocytes and antibody may bring about tumour infarction by their action on the endothelium of vessels supplying the tumour. The same process might account for the sudden loss of vision in the left eye of the patient.

Iridocyclitis and secondary glaucoma are well described as presenting features of secondary intraocular melanoma ${ }^{85-37}$ Black hypopyon may be an advanced manifestation of this phenomenon.

Finally, in considering the management of this difficult clinical problem 2 reports of uveitis and secondary glaucoma due to secondary intraocular melanoma responding to cytotoxic therapy should be mentioned. ${ }^{38}{ }^{39}$ It is interesting that both these cases eventually died of cerebral secondaries despite the fact that the intraocular secondaries had responded to the chemotherapy.

This report and others mentioned suggest that tumour necrosis may cause uveitis, secondary glaucoma, and even black hypopyon. Cytotoxic therapy may be more effective in treating tumour cells in aqueous suspension and causing a more gradual regression of the tumour mass. Radiotherapy may cause a more rapid tumour destruction. Our patient might have benefited from cytotoxic or immunotherapy when he first developed ocular complications. But these were withheld for fear of reducing his immunocompetence which was so effectively controlling his generalised disease.
.Fig. 4 Ultrasound photographs of the right and left eyes showing the irregularly raised retinal surface nasal to the disc of the left eye. The left eye is on the right.

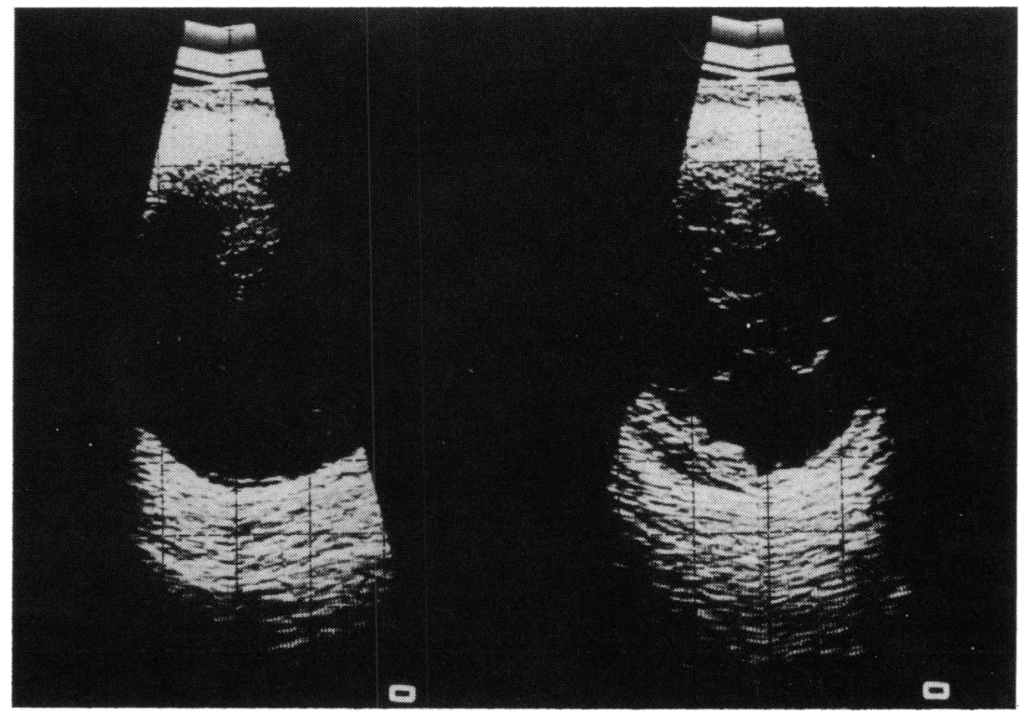


As the life expectancy of these patients is still very poor, these considerations are theoretical. It is interesting that all 3 cases of black hypopyon reported had evidence of tumour regression, either in response to treatment or spontaneously. In future if treatment for disseminated malignant disease becomes more effective these theoretical considerations may have greater clinical relevance.

We thank Mr P. D. Trevor Roper, Dr P. W. Copeman, Mr T. J. ffytche. Dr A. Macdonald. Dr S. Retsas. Mr R. A. Owen and Mr T. E. Tarrant and we are indebted to Miss C. Smyth for secretarial assistance.

\section{References}

1 Fuchs E. Das Sarkom des Uvealtrachtus. Vienna. 1882.

2 Landesberg. Casuistische Mittheilungen. III. Sarcom der Choroidea. Albrecht von Graefes Arch Klin Ophthalmol 1869; 15: 210-4.

3 Brömserg. Über einen Fall von sekundarem Melanom der Choroidea. Inaug. Dis., Berlin, 1870. Cited by Leber T, Bemerkung zu der vorhergehenden Mittheilung. Albrecht von Graefes Arch Klin Ophthalmol 1885; 31: 111-4.

4 Schiess-Gemuseus RM, Roth M. Metastatisches Sarkom der Papille und angrenzenden Retina. Albrecht von Graefes Arch Klin Ophthalmol 1879; 25: 177-90.

5 Pflüger W. Metastatisches Sarcom der Choroidea. Arch Augenheilkd 1885; 14: 129-32.

6 Wagenmann D. Ein fall von multiplen Melanosarkomen mit eigenartigen Komplikationen beider Augen. Dtsch Med Wochenschr 1900; 26: 262-3.

7 Jensen E. Ein Fall von Sarkommetastase in beiden Augen. Klin Monatsbl Augenheilkd 1906; 44: 580 (abstr).

8 Adamuk V. Ein Fall von metastatischen Melanosarkom der Uvea. Z Augenheilkd 1909; 21: 505.

9 Uhler EM. Metastatic malignant melanoma of the retina. Am J Ophthalmol 1914; 23: 158-62.

10 Ten Doesschate G. Ueber metastatisches Sarkom des Auges. Klin Monatsbl Augenheilkd 1921; 66: 766 (abstr).

11 Boente R. Metastatische Melanoblastome in der Retina. Klin Monatsbl Augenheilkd 1929; 82: 732-40.

12 Cordes FC, Horner WD. Metastatic melanoma of both eyes. JAMA 1930; 95: 655-8.

13 Corrado A. Sul sarcoma metastatico del corpo ciliare. Arch Ottalmol 1931; 38: 508-27.

14 Fry WE. Metastatic sarcoma of the choroid. Arch Ophthalmol 1933; 9: 248-55.

15 Kreibig W. Zur Kenntnis intraokularer Sarkommetastasen. $Z$ Augenheilkd 1935; 87: 265-84.

16 Wilder HC. Intraocular tumours in soldiers: world war II. Milit Surgeon 1946; 99: 459-90.

17 Radnot M. Metastatisches Melanosarkom der Strahlenkorpers in beiden Augen. Klin Monatsbl Augenheilkd 1952; 121: 352-4.
18 Jensen $\mathrm{OA}$. Choroidal metastasis from a malignant melanoma of the skin. Acta Ophthalmol (Kbh) 1957; 35: 91-6.

19 Liddicoat DA. Walter JR, Wilkinson WC. Retinal metastasis of malignant melanoblastoma. Am J Ophthalmol 1959; 48: 172-7.

20 Covell LL. Markiewitz HH. The choroid as site of prime manifestation of systemic involvement in skin melanoma. Am J Ophthalmol 1961; 51: 1296-303.

21 Riffenburgh RS. Metastatic malignant melanoma to the retina. Arch Ophthalmol 1961; 66: 487-9.

22 Das Gupta T. Brasfield R. Metastatic melanoma. Cancer 1964; 17: 1323-39.

23 Szeps J. Patterson TD. Metastatic malignant melanoma of ciliary body and choroid from a primary melanoma of skin. Can J Ophthalmol 1969; 4: 394-9.

24 Ferry AP. Primary malignant melanoma of the skin metastatic to the eye. Am J Ophthalmol 1972; 74: 12-9.

25 Gunther I. Augenmetastasen beim malignen melanom der Haut. Klin Monatsbl Augenheilkd 1973; 162: 821-3.

26 Kremlicka L, Roubova H, Cerna T. A case of ocular metastases of primary malignant melanoma of the skin. Cesk Oftalmol 1974; 30: $119-22$.

27 Ferry AP. Font RL. Carcinoma metastatic to the eye and orbit: a clinicopathologic study of 227 cases. Arch Ophthalmol 1974; 92: 276-86.

28 Lommatzsch $P$, Tost $M$. Intraokular metastasen bei primären Hautmelanomen. Klin Monatsbl Augenheilkd 1979; 174: 686.

29 Fishman ML. Tomaszewski MM, Kuwabara T. Malignant melanoma of the skin metastatic to the eye. Arch Ophthalmol 1976; 94: 1309-11.

30 Paton D. Thomas LB. Simultaneous occurrence of primary malignant melanomas of the eye and skin. Arch Ophthalmol 1959; 62: 135-42.

31 Bellet RE. Shields JA. Soll DB. Bernadino EA. Primary choroidal and cutaneous melanomas occurring in a patient with the B-K mole syndrome phenotype. Am J Ophthalmol 1980; 89: 567-70.

32 Albert DM. Lahav M. Troczynski E. Bahr R. Black hypopyon: report of two cases. Albrecht von Graefes Arch Klin Ophthalmol 1975; 193: 81-94.

33 Char DH. Schwartz A. Miller TR. Abele JS. Ocular metastases from systemic melanoma. Am J Ophthalmol 1980; 90: 702-7.

34 Reese AB, Archila EA, Jones IS. Cooper WC. Necrosis of malignant melanoma of the choroid. Am J Ophthalmol 1970; 69: 91-104.

35 Morgan WE, Malmgren RA, and Albert DM. Metastatic carcinoma of the ciliary body simulating uveitis. Arch Ophthalmol 1970; 83: 51-8.

36 Font RI, Naumann G, Zimmerman LE. Primary malignant melanoma of the skin metastatic to the eye and orbit. Am J Ophthalmol 1967; 63: 738-54.

37 Yanoff M. Scheie HG. Melanomalytic glaucoma. Arch Ophthalmol 1970; 84: 471-3.

38 Stark WJ, Rosenthal AR, Mullins GM, Greene WR. Simultaneous bilateral uveal melanomas responding to BCNU therapy. Trans Am Acad Ophthalmol Otolaryngol 1971; 75: 70-83.

39 Hirst LW, Reich J, Galbraith JE. Primary cutaneous malignant melanoma metastatic to the iris. Br J Ophthalmol 1979; 63: $165-8$. 